Quim. Nova, Vol. 36, No. 1, 16-20, 2013

\title{
NITROUS OXIDE EMISSIONS FROM AN INTERMITTENT AERATION ACTIVATED SLUDGE SYSTEM OF AN URBAN WASTEWATER TREATMENT PLANT
}

\author{
William Z. de Mello*, Renato P. Ribeiro e Ariane C. Brotto \\ Departamento de Geoquímica, Instituto de Química, Universidade Federal Fluminense, Outeiro São João Batista, s/n, $24020-141$ \\ Niterói - RJ, Brasil \\ Débora C. Kligerman, Andrezza de S. Piccoli e Jaime L. M. Oliveira \\ Departamento de Saneamento e Saúde Ambiental, Escola Nacional de Saúde Pública, Fundação Oswaldo Cruz, Rua Leopoldo \\ Bulhões, 1480, 21041-210 Rio de Janeiro - RJ, Brasil \\ Recebido em 26/1/12; aceito em 13/7/12; publicado na web em 29/11/12
}

\begin{abstract}
This study investigated the emission of $\mathrm{N}_{2} \mathrm{O}$ during the sequential aerated (60-min) and non-aerated (30-min) stages of an intermittent aeration cycle in an activated sludge wastewater treatment plant (WWTP). $\mathrm{N}_{2} \mathrm{O}$ emission occurred during both stages; however, emission was much higher during aeration. Air stripping is the major factor controlling transfer of $\mathrm{N}_{2} \mathrm{O}$ from the sewage to the atmosphere. The $\mathrm{N}_{2} \mathrm{O}$ emissions exclusively from the aeration tank represented $0.10 \%$ of the influent total nitrogen load and the per capita emission factor was almost 3 times higher than that suggested by the IPCC for inventories of $\mathrm{N}_{2} \mathrm{O}$ emission from WWTPs.
\end{abstract}

Keywords: nitrous oxide; wastewater treatment; intermittent aeration.

\section{INTRODUCTION}

Nitrous oxide $\left(\mathrm{N}_{2} \mathrm{O}\right)$ is an important greenhouse gas $(\mathrm{GHG})$ and a stratospheric ozone $\left(\mathrm{O}_{3}\right)$-depleting substance (ODS). Nitrous oxide has a global warming potential 310 and 15 times higher than those of carbon dioxide and methane, respectively, and is expected to become the dominant ODS by the end of the $21^{\text {st }}$ century. ${ }^{1}$ Atmospheric $\mathrm{N}_{2} \mathrm{O}$ concentration has increased by almost $20 \%$ since the middle of the $18^{\text {th }}$ century and continues to rise at a rate of approximately $0.25 \% \mathrm{yr}^{-1}$.,3

Nitrous oxide is naturally produced by a variety of aerobic and anaerobic microbial processes in pristine aquatic and terrestrial environments. However, human activities are increasingly altering the global biogeochemical cycle of nitrogen $(\mathrm{N})$ and consequently increasing $\mathrm{N}_{2} \mathrm{O}$ emissions. Human-related sources of $\mathrm{N}_{2} \mathrm{O}$ include biological wastewater treatment systems, where the microbial processes responsible for its production are basically the same as those occurring in natural environments. Global $\mathrm{N}_{2} \mathrm{O}$ emission from domestic wastewater treatment is believed to represent a small fraction of overall $\mathrm{N}_{2} \mathrm{O}$ sources, especially if the emission factor $\left(3.2 \mathrm{~g} \mathrm{~N}_{2} \mathrm{O}\right.$ person ${ }^{-1}$ $\left.\mathrm{yr}^{-1}\right)$, recommended by the IPCC ${ }^{4}$ for countries with predominantly advanced centralized wastewater treatment plants (WWTPs) with controlled nitrification and denitrification steps, is applied to $\mathrm{N}_{2} \mathrm{O}$ emission inventories. This emission factor $(\mathrm{EF})$ was determined by Czepiel et al. ${ }^{5}$ at a WWTP in Northeastern United States. The 2006 IPCC Guidelines for National GHG Inventories points out that there is no other country-specific EF available. It is noteworthy to point out that studies on full-scale WWTPs remain limited and the variability between reported EFs is considerable. ${ }^{6-10}$

There is also a need for better understanding of the major processes controlling $\mathrm{N}_{2} \mathrm{O}$ production and emission from full-scale WWTPs. Kampschreur et al. ${ }^{7}$ provided a literature review on major biological processes and key operating parameters controlling $\mathrm{N}_{2} \mathrm{O}$ emissions from WWTPs. In full-scale WWTPs, $\mathrm{N}_{2} \mathrm{O}$ is emitted predominantly from activated sludge units..$^{5,70,11}$ In these units, it has been proposed that $\mathrm{N}_{2} \mathrm{O}$ is produced mostly as a result of nitrite $\left(\mathrm{NO}_{2}^{-}\right)$reduction

*e-mail: zamboni@geoq.uff.br by ammonia-oxidizing bacteria (AOB), i.e. a process called nitrifier denitrification. ${ }^{12-16}$ Laboratory and full-scale studies have suggested that the main operating conditions leading to elevated $\mathrm{N}_{2} \mathrm{O}$ production are: dissolved oxygen concentration $\leq 1 \mathrm{mg} \mathrm{O}_{2} \mathrm{~L}^{-1}$; elevated nitrite concentrations, and low chemical oxygen demand (COD) to nitrogen ratio. $8,14,15,17-19$

In our previous study, ${ }^{11}$ we focused on estimating $\mathrm{N}_{2} \mathrm{O}$ emissions from an activated sludge WWTP with prolonged aeration process and found that approximately $90 \%$ of $\mathrm{N}_{2} \mathrm{O}$ emissions derived from the aeration tank, which was consistent with the findings of Czepiel et al. ${ }^{5}$ The aim of the present study was to investigate $\mathrm{N}_{2} \mathrm{O}$ emission and production during both aerated and non-aerated sequential stages in the intermittent aeration process of an activated sludge WWTP. Hitherto, as far as we know, there is only one study available on $\mathrm{N}_{2} \mathrm{O}$ emissions from full-scale domestic wastewater treatment with the intermittent aeration process. ${ }^{20}$ However, three other studies on $\mathrm{N}_{2} \mathrm{O}$ emissions from intermittent aeration processes have been conducted, two on a lab-scale with domestic wastewater and one full-scale study of swine wastewater. ${ }^{17,18,21}$

\section{EXPERIMENTAL}

\section{Location and characteristics of the WWTP}

The study was carried out from 22 to 27 August 2009 at a WWTP located within a municipality in the highlands of Rio de Janeiro state. The city is at an altitude of approximately $600 \mathrm{~m}$ above sea level. The local climate is classified as humid subtropical (Köppen Cwa). The annual average precipitation and temperature are $1390 \mathrm{~mm}$ and 19.5 ${ }^{\circ} \mathrm{C}$, with monthly averages ranging from $31 \mathrm{~mm}$ (July) and $16.3^{\circ} \mathrm{C}$ (July) to $258 \mathrm{~mm}$ (December) and $22.6{ }^{\circ} \mathrm{C}$ (February). ${ }^{22}$ The reduced chance of rainfall in winter was decisive in the choice of this period to conduct studies involving time-sequential sampling methods, as heavy rains could have affected the results due to dilution.

The studied WWTP serves a population of about 2000 people, treats approximately $600 \mathrm{~m}^{3}$ day $^{-1}$ of exclusively domestic wastewater, and utilizes an activated sludge with intermittent aeration process. The aeration tank in which the study was conducted had an internal 
surface area of $60 \mathrm{~m}^{2}$ and a volume of $120 \mathrm{~m}^{3}$. The hydraulic and sludge retention times were $4.8 \mathrm{~h}$ and 13 days, respectively. The tank is rectangular and covered on the top side, having three openings $\left(0.64 \mathrm{~m}^{2}\right.$ each $)$ through which measurements and sampling was carried out. For practical purposes, we named these openings as A, B and C (Figure 1S, supplementary material). According to the reactor design, the sewage flows from opening A towards $\mathrm{C}$. The intermittent aeration cycle consists of $60 \mathrm{~min}$ aerated and $30 \mathrm{~min}$ non-aerated stages, with air injected at a flow rate of $640 \mathrm{~m}^{3} \mathrm{~h}^{-1}$ by an air distribution system composed of 150 rubber membrane diffusers positioned at the bottom of the tank.

\section{Sampling and analysis}

Nitrous oxide emissions were measured consecutively during the aerated and non-aerated stages of one complete intermittent aeration cycle of 90 min duration for 6 consecutive days. During the aerated stage, sampling and measurements were performed at openings A and $\mathrm{B}$, and in the absence of aeration, at openings $\mathrm{A}, \mathrm{B}$ and $\mathrm{C}$ simultaneously. For each of these stages, a specific sampling technique for $\mathrm{N}_{2} \mathrm{O}$ flux determination was employed.

During aeration, sampling and measurements were taken alternately at openings A and B, consequently initiation began 5 or 10 min after the start of aeration. At this stage, insufficient manpower prevented measurements from being taken at opening $\mathrm{C}$ since two people were required for the $\mathrm{N}_{2} \mathrm{O}$ sampling procedure. The technique applied for determining $\mathrm{N}_{2} \mathrm{O}$ emissions during aeration, described in-detail by Brotto et al., ${ }^{11}$ consists of capturing air bubbles stripped from the liquid during aeration using an upturned $30-\mathrm{cm}$ diameter plastic funnel which makes the rising bubbles converge toward its narrower end (funnel headspace) from which air samples are withdrawn for further analysis. ${ }^{11}$ During sampling, one person holds the funnel while the other takes the sample. Before sample removal, the funnel was maintained almost entirely submerged for about $3 \mathrm{~min}$ in order to stabilize the $\mathrm{N}_{2} \mathrm{O}$ concentration (from bubble bursts) inside the funnel headspace. This procedure allowed the remaining ambient air to be completely removed from the funnel headspace avoiding sample dilution. The $\mathrm{N}_{2} \mathrm{O}$ emission rate (ER) was calculated as follows:

$$
\mathrm{ER}=\mathrm{Q} \times \Delta \mathrm{C}
$$

where $\mathrm{Q}$ is the flow rate of air injected into the tank during the aeration stage $\left(640 \mathrm{~m}^{3} \mathrm{~h}^{-1}\right)$ and $\Delta \mathrm{C}$ is the $\mathrm{N}_{2} \mathrm{O}$ concentration in the air stripped from the liquid minus the ambient air $\mathrm{N}_{2} \mathrm{O}$ concentration (ca. 325 ppb). The $\mathrm{N}_{2} \mathrm{O}$ emission flux $\left(\mathrm{N}_{2} \mathrm{O}\right.$ mass per unit area per unit time) during the aerated stage was calculated by dividing the $\mathrm{N}_{2} \mathrm{O}$ emission rate by the surface area of the aeration tank.

During the 30-min non-aerated stage, closed PVC chambers (24 $\mathrm{cm}$ diameter and 10-cm height) were employed to directly measure the $\mathrm{N}_{2} \mathrm{O}$ emission fluxes at the liquid-air interface. ${ }^{11}$ For flotation, styrofoam plates were set around the chambers, which were settled on the liquid surface approximately 2 min after aeration had ceased. Samples were withdrawn from chambers at 5-min intervals for 20 min by means of $20-\mathrm{mL}$ syringes. The $\mathrm{N}_{2} \mathrm{O}$ emission flux (F) was calculated as follows:

$$
\mathrm{F}=\mathrm{h} \times \mathrm{dC} /\left.\mathrm{dt}\right|_{\mathrm{t}=0}
$$

where $\mathrm{h}$ is the inner chamber height above the liquid surface and $\mathrm{dC} /\left.\mathrm{dt}\right|_{\mathrm{t}=0}$ is the $\mathrm{N}_{2} \mathrm{O}$ concentration change as a function of time at $\mathrm{t}=0$. In practice, the flux is calculated at the initial linear segment of the curve.

Nitrous oxide concentration in the liquid was determined at opening B only, by the headspace gas method. First, a $30-\mathrm{mL}$ wastewater sample was collected using a $60-\mathrm{mL}$ syringe followed by an equal volume of ambient air. Second, the syringe was manually shaken 200 times ( 1 $\mathrm{min}$ ) and the headspace carefully transferred to a dry 20 -mL syringe. ${ }^{5,11,23}$ Finally, after analysis, $\mathrm{N}_{2} \mathrm{O}$ concentration $\left(\mathrm{C}\right.$; in $\left.\mathrm{nmol} \mathrm{L} \mathrm{L}^{-1}\right)$ in the liquid was calculated as follows:

$$
\mathrm{C}=\left(\mathrm{K}_{0} \times \mathrm{C}_{\mathrm{hs}}\right)+\left[(\mathrm{P} / \mathrm{RT}) \times\left(\mathrm{C}_{\mathrm{hs}}-\mathrm{C}_{\text {air }}\right)\right]
$$

where $\mathrm{C}_{\mathrm{hs}}$ and $\mathrm{C}_{\text {air }}$ are the $\mathrm{N}_{2} \mathrm{O}$ concentrations (ppb; parts per billion by volume) in the syringe headspace (after shaking) and the ambient air $\mathrm{N}_{2} \mathrm{O}$ ( ca. $\left.325 \mathrm{ppb}\right), \mathrm{K}_{0}$ is the $\mathrm{N}_{2} \mathrm{O}$ solubility coefficient, ${ }^{24} \mathrm{P}$ the ambient air pressure, $\mathrm{R}$ the gas constant $\left(0.082 \mathrm{~L}\right.$ atm K $\left.\mathrm{K}^{-1} \mathrm{~mol}^{-1}\right)$, and $\mathrm{T}$ the liquid temperature.

All ambient air and headspace samples were analyzed for $\mathrm{N}_{2} \mathrm{O}$ within $8 \mathrm{~h}$ of collection on a Shimadzu GC-17A gas chromatograph (GC) equipped with a ${ }^{63} \mathrm{Ni}$ electron capture detector and a packed Porapak-Q column. The GC was temporarily installed at a site near the investigated WWTP. Argon with 5\% methane was used as a carrier gas at a $40 \mathrm{~mL} \mathrm{~min}^{-1}$ flow rate. Calibration standards (356 and $840 \mathrm{ppb}$ ) were acquired from White Martins. Analytical precision was $\pm 1 \%$ and the quantification limit for the upturned funnel and the floating chamber technique were $4 \times 10^{-3} \mathrm{~g} \mathrm{~N}_{2} \mathrm{O} \mathrm{h}^{-1}$ (Equation 1) and $1.4 \mu \mathrm{g}$ $\mathrm{N}_{2} \mathrm{O} \mathrm{m}^{-2} \mathrm{~h}^{-1}$ (Equation 2), respectively.

In situ measurements of dissolved oxygen (DO), $\mathrm{pH}$ and temperature were made $20-30 \mathrm{~cm}$ below the liquid surface using a Hanna Instruments HI9828 multiparameter portable meter, calibrated daily. Liquid samples for determination of $\mathrm{NH}_{4}{ }^{+}, \mathrm{NO}_{2}{ }^{-}$and nitrate $\left(\mathrm{NO}_{3}{ }^{-}\right)$ were collected, filtered through $0.22-\mu \mathrm{m}$ cellulose acetate membrane filters, and stored frozen until later analyses. Ammonium was determined spectrophotometrically by the indophenol blue method (absorbance measured at $640 \mathrm{~nm}$ ). Nitrite was determined spectrophotometrically through formation of a reddish purple azo dye by coupling diazotized sulfanilic acid with NED dihydrochloride. ${ }^{25}$ Nitrate was determined after reduction (in $\mathrm{Cd}-\mathrm{Cu}$ column) to $\mathrm{NO}_{2}$. The detection limits for ammonium, nitrite, and nitrate were 0.02 , 0.001 , and $0.01 \mathrm{mg} \mathrm{N} \mathrm{L}^{-1}$, respectively. The COD was determined using the colorimetric method following oxidation by digestion with an acid-dichromate solution. ${ }^{25}$

\section{RESULTS AND DISCUSSION}

\section{Wastewater characteristics}

The COD and dissolved inorganic N (DIN) concentrations measured during the study period in the WWTP influent and effluent are compiled in Table 1 . The influent average COD and DIN concentrations were $217 \mathrm{mg} \mathrm{L}^{-1}$ and $28 \mathrm{mg} \mathrm{N} \mathrm{L}^{-1}$. These parameters characterize the sewage as a weak-strength wastewater with respect

Table 1. Chemical oxygen demand $\left(\mathrm{mg} \mathrm{L}^{-1}\right)$ and concentrations of inorganic nitrogen compounds $\left(\mathrm{mg} \mathrm{N} \mathrm{L}^{-1}\right)$ in the wastewater treatment plant influent and effluent

\begin{tabular}{ccc}
\hline & Influent & Effluent \\
\hline $\mathrm{COD}$ & $217 \pm 67$ & $35 \pm 11$ \\
$\mathrm{NH}_{4}^{+}$ & $27.5 \pm 7.11$ & $13.4 \pm 3.07$ \\
$\mathrm{NO}_{2}^{-}$ & $0.03 \pm 0.01$ & $0.28 \pm 0.29$ \\
$\mathrm{NO}_{3}^{-}$ & $0.13 \pm 0.04$ & $0.89 \pm 1.20$ \\
Total INC & $28 \pm 7.1$ & $15 \pm 2.2$ \\
\hline
\end{tabular}

$\mathrm{COD}=$ Chemical oxygen demand; $\mathrm{INC}=$ inorganic nitrogen compounds; Total INC: $\mathrm{NH}_{4}^{+}+\mathrm{NO}_{2}^{-}+\mathrm{NO}_{3}^{-}$. 
to the former and as a medium-strength wastewater with respect to the latter. ${ }^{26}$ The average COD removal efficiency was $82 \pm 8.7 \%$, with a maximum removal efficiency of $90-91 \%$. During the study period the liquid temperature and $\mathrm{pH}$ ranged from 19 to $20^{\circ} \mathrm{C}$ and 6.3 to 6.9 , respectively.

\section{Nitrous oxide emission}

Nitrous oxide emissions were detected during both the 60 -min aerated and 30-min non-aerated stages of the intermittent aeration cycle. Emissions were much higher during the aerated stage than the non-aerated stage. Figure 1 provides a compilation of all $\mathrm{N}_{2} \mathrm{O}$ flux measurements performed during the 6-day study period and shows the evolution of $\mathrm{N}_{2} \mathrm{O}$ emissions from the liquid during both stages. $\mathrm{N}_{2} \mathrm{O}$ emissions increased exponentially throughout the aerated stage and, in some cases, stabilized in the final 20-30 min of the aeration process. These results reveal that during aeration air stripping is the major process controlling $\mathrm{N}_{2} \mathrm{O}$ transfer from the liquid to the atmosphere. In the absence of aeration, combined molecular diffusion and remaining turbulence from the preceding aeration, are the major processes controlling $\mathrm{N}_{2} \mathrm{O}$ transfer.

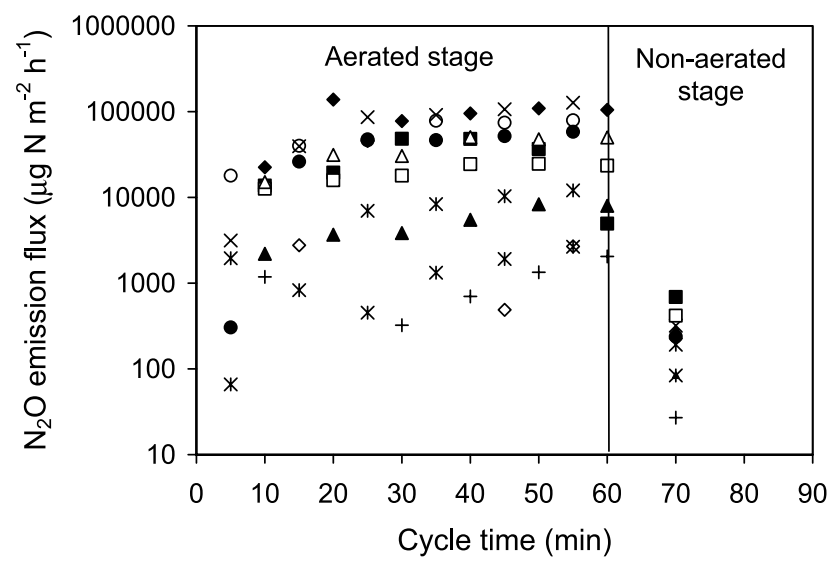

Figure 1. Time variability of nitrous oxide emissions measured, from 22 to 27 August 2009, during the sequential 60-min aerated and 30-min nonaerated stages

The $\mathrm{N}_{2} \mathrm{O}$ fluxes for the entire 60-min aerated stage of each series of measurements were estimated by combining the data for the six 10-min time interval flux measurements shown in Figure 2. These $\mathrm{N}_{2} \mathrm{O}$ fluxes, together with fluxes measured directly using the chambers during the non-aerated stage, are all shown in Table 2. The mean (and median) $\mathrm{N}_{2} \mathrm{O}$ fluxes for the aerated and non-aerated stages were $49.8(46.0) \mathrm{mg} \mathrm{N}_{2} \mathrm{O} \mathrm{m}^{-2} \mathrm{~h}^{-1}(\mathrm{n}=11)$ and $0.37(0.37)$ $\mathrm{mg} \mathrm{N} \mathrm{N}_{2} \mathrm{O} \mathrm{m}^{-2} \mathrm{~h}^{-1}(\mathrm{n}=13)$, respectively. Three out of the total 27 measurements were rejected due to error in sampling or analysis. Given that the aerated and non-aerated stages run for 16 and $8 \mathrm{~h}$ day $^{-1}$, respectively, the estimated time-weighted daily emission rates (flux $\times$ tank area) for the aerated and non-aerated stages are 47.8 and $0.18 \mathrm{~g} \mathrm{~N}_{2} \mathrm{O}$ day ${ }^{-1}$, respectively, giving a total of $48.0 \mathrm{~g} \mathrm{~N}_{2} \mathrm{O}$ day $^{-1}$ (or $14.9 \mathrm{~kg} \mathrm{CO}_{2}$-eq day ${ }^{-1}$ as $\mathrm{CO}_{2}$ equivalent). Accordingly, $99.6 \%$ of the daily $\mathrm{N}_{2} \mathrm{O}$ emissions from the aeration tank occurred during the aerated stage.

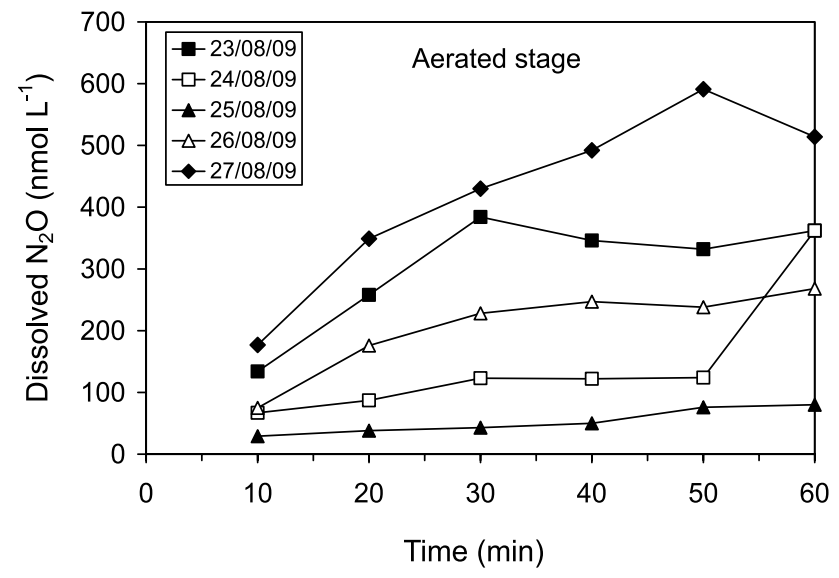

Figure 2. Time variability of dissolved nitrous oxide concentrations measured during the 60-min aerated stage (symbols indicating the sampling date are in conformity to those shown in Figure 1)

$\mathrm{N}_{2} \mathrm{O}$ emission fluxes varied among openings with variations less pronounced during aeration (Table 2). For both stages, the $\mathrm{N}_{2} \mathrm{O}$ emissions decreased mostly from opening A towards $\mathrm{C}$, following the sewage flow through the aeration tank. Therefore, this variation can be attributed to a decrease in substrate (e.g. $\mathrm{NH}_{4}{ }^{+}$and $\mathrm{NO}_{2}{ }^{-}$) concentrations as the wastewater moves through the tank. Homogenization caused by turbulence during aeration explains the lower variation in $\mathrm{N}_{2} \mathrm{O}$ emissions during this stage.

Despite the flux measurements, which were always performed at around the same time of day, the daily variation in $\mathrm{N}_{2} \mathrm{O}$ emissions (almost two orders of magnitude) is remarkable and was more pronounced during the aerated stage (Table 2). The highest emission values were found in the last two sampling days (i.e., 26 and 27 August) when emissions during aeration were, on average, 6 and 13 times higher, respectively, than those measured on 25 August. On the morning of 26 , before flux measurements started, for operational reasons approximately $1 / 3$ of the aeration tank volume was drained and immediately replaced by raw sewage. Therefore, the sudden fresh supply of reduced $\mathrm{N}$ compounds, i.e., predominantly $\mathrm{NH}_{4}^{+}$and organic-N forms, is the most plausible explanation for the elevated $\mathrm{N}_{2} \mathrm{O}$ emissions observed on 26 and 27 August.

Table 2. Nitrous oxide emission fluxes $\left(\mathrm{mg} \mathrm{N}_{2} \mathrm{O} \mathrm{m}^{-2} \mathrm{~h}^{-1}\right)$ from liquid during one cycle of the intermittent aeration system

\begin{tabular}{|c|c|c|c|c|c|c|}
\hline & 22/08/09 & $23 / 08 / 09$ & $24 / 08 / 09$ & 25/08/09 & 26/08/09 & $27 / 08 / 09$ \\
\hline \multicolumn{7}{|c|}{ Aerated stage (60 min) } \\
\hline Opening A & 2.41 & 88.2 & n.d. & 10.6 & 60.3 & 118 \\
\hline Opening B & 2.19 & 46.0 & 29.3 & 7.32 & 52.6 & 131 \\
\hline \multicolumn{7}{|c|}{ Non-aerated stage (30 min) } \\
\hline Opening A & 0.30 & 1.09 & n.d. & 0.50 & 0.66 & n.d. \\
\hline Opening B & 0.03 & 0.45 & 0.13 & 0.13 & 0.37 & n.d. \\
\hline Opening $\mathrm{C}$ & n.d. & 0.61 & 0.09 & 0.03 & 0.38 & n.d. \\
\hline
\end{tabular}

n.d. $=$ Not determined. 


\section{Nitrous oxide production}

Akin to emissions, dissolved $\mathrm{N}_{2} \mathrm{O}$ concentrations in the liquid increased gradually during aeration and varied between sampling days (Figure 2). During the second half of the aerated stage, $\mathrm{N}_{2} \mathrm{O}$ accumulation appears to converge towards an equilibrium condition between production and evasion to the atmosphere. The observed accumulation of $\mathrm{N}_{2} \mathrm{O}$ in the liquid, while partially being transferred to the atmosphere by air stripping, denotes its production by microbiological processes throughout the aerated stage.

The $\mathrm{N}_{2} \mathrm{O}$ and dissolved oxygen (DO) concentrations were simultaneously determined in the liquid during the aerated and non-aerated stages sequentially on 25 and 26 August only. Figure 3 shows the evolution of $\mathrm{N}_{2} \mathrm{O}$ and DO concentrations throughout both stages. Both concentrations increased throughout the aerated stage until aeration ceased. Thereafter, DO concentrations fell to $0 \mathrm{mg} \mathrm{L}^{-1}$ within $10 \mathrm{~min}$ while $\mathrm{N}_{2} \mathrm{O}$ concentrations continued to rise, albeit inconsistently, since there were clear dips in dissolved $\mathrm{N}_{2} \mathrm{O}$ concentrations. This behavior suggests a possible shift of processes involving production or even consumption of $\mathrm{N}_{2} \mathrm{O}$ during the non-aerated stage. Further investigations are needed to better understand the factors responsible for the production and consumption of $\mathrm{N}_{2} \mathrm{O}$ during this stage.

The $\mathrm{N}_{2} \mathrm{O}$ emission rate, which corresponds to the fraction of $\mathrm{N}_{2} \mathrm{O}$ produced by microbiological processes in the sewage and thereby released into the atmosphere, and the dissolved $\mathrm{N}_{2} \mathrm{O}$ accumulation rate, which corresponds to the fraction built up in the sewage over the same time interval, for both aerated and non-aerated stages are shown in Table 3. The sum represents the total net $\mathrm{N}_{2} \mathrm{O}$ production rate in the sewage. The results suggest that $50-75 \%$ of the total net production of $\mathrm{N}_{2} \mathrm{O}$ was released into the atmosphere during aeration and, despite the limited data, that less than $1 \%$ was released in the absence of aeration. It is also likely that part of the dissolved $\mathrm{N}_{2} \mathrm{O}$ accumulated in the sewage during this stage is transferred to the atmosphere by air stripping as soon as aeration is resumed.

\section{Nitrous oxide conversion ratio and emission factors}

Ammonium and organic $\mathrm{N}$ are the predominant forms of $\mathrm{N}$ in domestic wastewater. In this work, no measurement of total N (TN) concentration in the influent wastewater was made. Therefore, based on the population served by the WWTP (2000 people), the average wastewater inflow rate $\left(600 \mathrm{~m}^{3}\right.$ day $\left.^{-1}\right)$, and the assumption of a per capita wastewater total $\mathrm{N}$ load of $15 \mathrm{~g} \mathrm{~N}$ person ${ }^{-1}$ day $^{-1},{ }^{27}$ we estimated a TN concentration of $50 \mathrm{mg} \mathrm{N} \mathrm{L}^{-1}$. This value seems reasonable considering that the average total inorganic $\mathrm{N}$ concentration in the wastewater influent was $28 \mathrm{mg} \mathrm{N} \mathrm{L}^{-1}$ (Table 1) and that approximately $50-60 \%$ of $\mathrm{TN}$ in domestic wastewater is formed by inorganic N. ${ }^{17,26,28}$ Accordingly, it is likely that the WWTP treats approximately
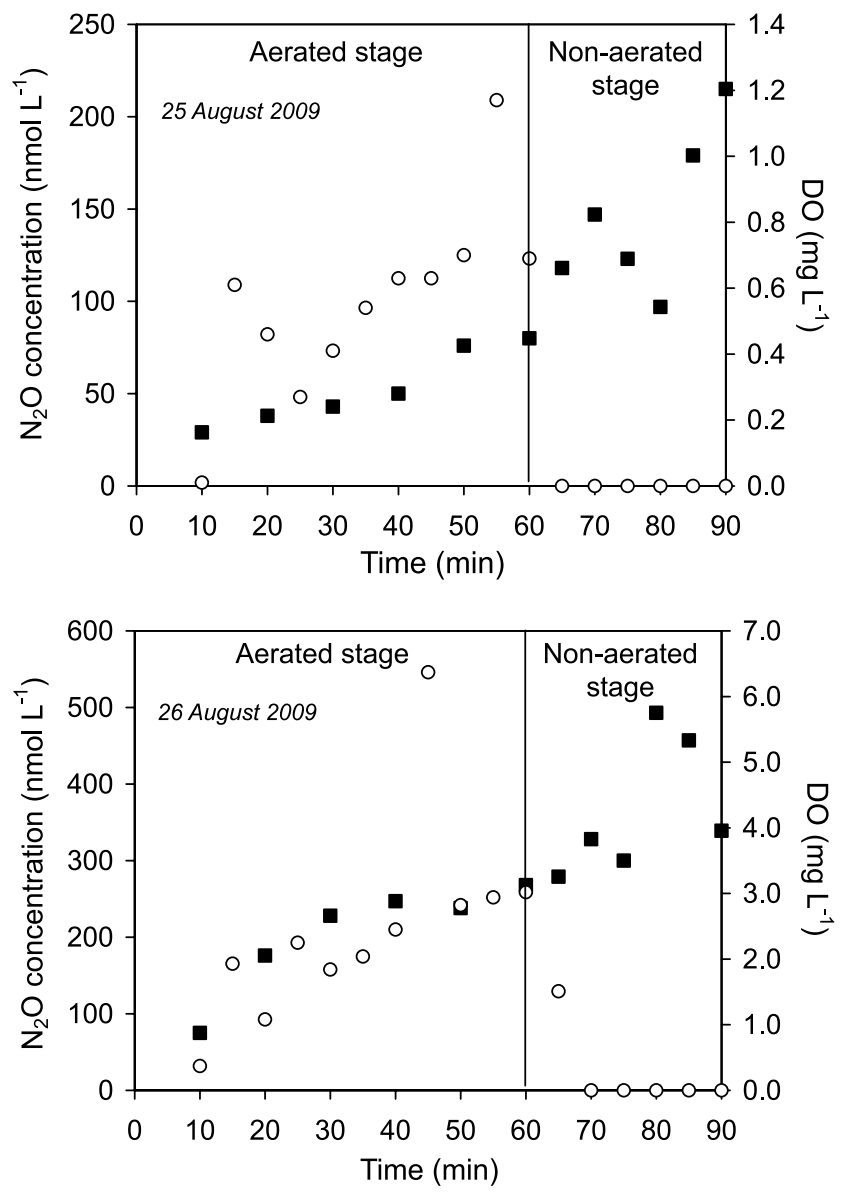

Figure 3. Time variability of dissolved nitrous oxide ( $\mathbf{\square})$ and oxygen $(\bigcirc)$ concentrations measured during the sequential 60-min aerated and 30-min non-aerated stages on 25 and 26 August 2009

$30 \mathrm{~kg} \mathrm{~N}$ day $^{-1}$ of which $0.10 \%$ is converted to $\mathrm{N}_{2} \mathrm{O}$ in its intermittent aeration-type activated sludge system.

The $\mathrm{N}_{2} \mathrm{O}$ conversion ratio found in this study seems highly consistent with the figures reported by Kimochi et al. ${ }^{20}$ who found that the higher the $\mathrm{N}_{2} \mathrm{O}$ conversion ratio the longer the aerated/nonaerated time period of the intermittent aeration cycle. Their experiments consisted of $30 \mathrm{~min} / 30 \mathrm{~min}, 30 \mathrm{~min} / 60 \mathrm{~min}$ and $30 \mathrm{~min} / 90 \mathrm{~min}$ aeration/non-aeration periods which yielded $\mathrm{N}_{2} \mathrm{O}$ conversion ratios of $0.08,0.05$ and $0.01 \%$, respectively. Our results, based on a $60 \mathrm{~min} / 30 \mathrm{~min}$ period, were broadly consistent with those reported by Kimochi et al.. ${ }^{20}$

In a previous study by our group carried out in an activated sludge

Table 3. Net nitrous oxide production rate $\left(\mathrm{g} \mathrm{N}_{2} \mathrm{O} \mathrm{h}^{-1}\right)$ in the liquid during one cycle of the intermittent aeration system

\begin{tabular}{|c|c|c|c|c|c|c|}
\hline & $22 / 08 / 09$ & $23 / 08 / 09$ & $24 / 08 / 09$ & $25 / 08 / 09$ & $26 / 08 / 09$ & $27 / 08 / 09$ \\
\hline \multicolumn{7}{|c|}{ Aerated stage (60 min) } \\
\hline Emitted & 0.13 & 2.76 & 1.76 & 0.44 & 3.16 & 7.86 \\
\hline Non-emitted & n.d. & 1.86 & 1.66 & 0.32 & 1.55 & 2.69 \\
\hline Total & - & 4.62 & 3.42 & 0.76 & 4.71 & 10.6 \\
\hline \multicolumn{7}{|c|}{ Non-aerated stage (30 min) } \\
\hline Emitted & $<0.01$ & 0.03 & $<0.01$ & 0.01 & 0.02 & n.d. \\
\hline Non-emitted & n.d. & n.d. & n.d. & 1.43 & 0.75 & n.d. \\
\hline Total & - & - & - & 1.44 & 0.77 & - \\
\hline
\end{tabular}

n.d. = Not determined. 
WWTP with a prolonged aeration process, we found a $\mathrm{N}_{2} \mathrm{O}$ emission factor of $0.14 \% .{ }^{11}$ Our results are consistent with those reported by Ahn et al. ${ }^{10}$ from twelve WWTPs operated with biological nitrogen removal (BNR) and non-BNR systems, which ranged from 0.01 to $1.8 \%$. On the other hand, in a review of $\mathrm{N}_{2} \mathrm{O}$ emissions from various WWTPs, Kampschreur et al. ${ }^{7}$ reported an upper limit which as approximately two orders of magnitude higher (0-14.6\%) than our mean values. Similarly, in Australia, a survey including seven fullscale biological nutrient removal wastewater systems provided $\mathrm{N}_{2} \mathrm{O}$ conversion ratios ranging from 0.6 to $25.3 \%$. $^{8}$

Based on the population served, we estimated a daily per capita $\mathrm{N}_{2} \mathrm{O}$ emission (from the aeration tank only) in the order of $2.4 \times 10^{-2} \mathrm{~g} \mathrm{~N}_{2} \mathrm{O}$ person $^{-1}$ day $^{-1}$, higher than the emission factor $\left(0.9 \times 10^{-2} \mathrm{~g} \mathrm{~N}_{2} \mathrm{O}\right.$ person ${ }^{-1}$ day $^{-1}$ or $3.2 \mathrm{~g} \mathrm{~N}_{2} \mathrm{O}$ person $\left.{ }^{-1} \mathrm{yr}^{-1}\right)$ recommended by the $\mathrm{IPCC}^{4}$ for countries with predominantly advanced centralized WWTPs involving controlled nitrification and denitrification steps. The flow-based emission factor was estimated as $8.0 \times 10^{-5} \mathrm{~g} \mathrm{~N}_{2} \mathrm{O} \mathrm{L}$ (wastewater) $)^{-1}$. However, it is noteworthy that the activated sludge system studied was not configured to achieve reliable biological nitrogen removal and that the efficiency of nitrogen removal was not evaluated.

\section{CONCLUSIONS}

In an intermittent aeration system of an urban WWTP operated with an aerated/non-aerated cycle of 60/30 min, $\mathrm{N}_{2} \mathrm{O}$ was produced and emitted into the atmosphere during both the aerated and non-aerated stages. Emissions were much higher during aeration and air stripping was the major process controlling $\mathrm{N}_{2} \mathrm{O}$ transfer from the sewage to the atmosphere. The fresh supply of reduced $\mathrm{N}$ compounds $\left(\mathrm{NH}_{4}^{+}\right.$and organic- $\mathrm{N}$ forms) significantly stimulated emissions of $\mathrm{N}_{2} \mathrm{O}$. Approximately $0.10 \%$ of the influent total $\mathrm{N}$ load was converted and emitted as $\mathrm{N}_{2} \mathrm{O}$ into the atmosphere. The per capita emission factor (for the aeration tank only) was almost 3 times higher than that suggested by the IPCC (2006) applicable to $\mathrm{N}_{2} \mathrm{O}$ emission inventories for countries with predominantly advanced centralized WWTPs involving controlled nitrification and denitrification phases. In WWTPs with activated sludge systems, aeration should effectively reduce the organic load of sewage treated, but in parallel must also minimize $\mathrm{N}_{2} \mathrm{O}$ emissions.

\section{SUPPLEMENTARY MATERIAL}

Available at http://quimicanova.sbq.org.br, in the form of a PDF file with free access. Figure 1S. Covered aeration tank of wastewater treatment plant and openings (A, B and C) through which all measurements were made.

\section{ACKNOWLEDGEMENTS}

This research was supported by $\mathrm{CNPq}$ and FAPERJ under grants 0477 (Programa Estratégico de Pesquisa em Saúde - Fiocruz/CNPq) and E-26/112.140/2008, respectively. The CAPES provided the Masters Scholarship to A. de S. Piccoli, and the CNPq provided the PQ fellowship to W. Z. de Mello (301421-2009/9) and IC fellowship (PIBIC/Fiocruz) to R. P. Ribeiro.

\section{REFERENCES}

1. Ravishankara, A. R.; Daniel, J. S.; Portman, R. W.; Science 2009, 326, 123.

2. Artuso, F.; Chamard, P.; Chiavarini, S.; di Sarra, A.; Meloni, D.; Piacentino, S.; Sferlazzo, M. D.; Atmos. Environ. 2010, 44, 4944.

3. IPCC - Intergovernmental Panel on Climate Change; Climate Change 2007: The Physical Science Basis - Contribution of Working Group I to the Fourth Assessment Report of the Intergovernmental Panel on Climate Change, Cambridge, 2007.

4. IPCC - Intergovernmental Panel on Climate Change; 2006 IPCC Guidelines for National Greenhouse Gas Inventories, Waste - Vol. 5, Kanagawa, 2006.

5. Czepiel, P.; Crill, P.; Harriss, R.; Environ. Sci. Technol. 1995, 29, 2352.

6. Barton, P. K.; Atwater, J. W.; J. Environ. Eng. 2002, 128, 137.

7. Kampschreur, M. J.; Temmink, H.; Kleerebezem, R.; Jetten, M. S. M.; van Loosdrecht, M. C. M.; Water Res. 2009, 43, 4093.

8. Foley, J.; de Haas, D.; Yuan, Z.; Lant, P.; Water Res. 2010, 44, 831.

9. Bhunia, P.; Yan, S.; LeBlanc, R. J.; Tyagi, R. D.; Surampalli, R. Y.; Zhang, T. C.; J. Hazard. Toxic Radioact. Waste 2010, 14, 158.

10. Ahn, J. O.; Kim, S.; Park, H.; Rahm, B.; Pagilla, K.; Chandran, K.; Environ. Sci. Technol. 2010, 44, 4505.

11. Brotto, A. C.; Kligerman, D. C.; Piccoli, A. S.; de Mello, W. Z.; Quim. Nova 2010, 33, 618.

12. Gejlsbjerg, B.; Frette, L.; Westermann, P.; Water Res. 1998, 32, 2113.

13. Wrage, N.; Velthof, G. L.; van Beusichem, M .L.; Oenema, O.; Soil Biol. Biochem. 2001, 33, 1723.

14. Tallec, G.; Garnier, J.; Billen, G.; Gousailles, M.; Water Res. 2006, 40, 2972.

15. Kampschreur, M. J.; van der Star, W. R. L.; Wielders, H. A.; Mulder, J. W.; Jetten, M. S. M.; van Loosdrecht, M. C. M.; Water Res. 2008, 42, 812.

16. Kim, S. -W.; Miyahara. M.; Fushinobu, S.; Wakagi, T.; Shoun, H.; Bioresour. Technol. 2010, 101, 3958.

17. Park, K. Y.; Inamori, Y.; Mizuochi, M.; Ahn, K. H.; J. Biosci. Bioeng. 2000, 90, 247.

18. Itokawa, H.; Hanaki, K.; Matsuo, T.; Water Res. 2001, 35, 657.

19. Tallec, G.; Garnier, J.; Billen, G.; Gousailles, M.; Bioresour. Technol. 2008, 99, 2200 .

20. Kimochi, Y.; Inamori, Y.; Mizuochi, M.; Xu, K.-Q.; Matsumura, M.; J. Fermentation Bioeng. 1998, 86, 202.

21. Osada, T.; Kuroda, K.; Yonaga, M.; Water Res. 1995, 29, 1607.

22. FIDERJ - Fundação Instituto de Desenvolvimento Econômico e Social do Rio de Janeiro; Indicadores Climatológicos, Governadoria do Estado do Rio de Janeiro/Secretaria de Planejamento e Coordenação Geral, Rio de Janeiro, 1978.

23. Guimarães, G. P.; de Mello, W. Z.; Quim. Nova 2008, 31, 1613.

24. Weiss, R. F.; Price, B. A.; Mar. Chem. 1980, 8, 347.

25. Eaton, A. D.; Clesceri, L. S.; Greenberg, A. E.; Standard Methods for the Examination of Water and Wastewater, $19^{\text {th }}$ ed.; American Public Health Association: Washington, 1995.

26. Jordão, E. P.; Pessôa, C. A.; Tratamento de Esgotos Domésticos, SEGRAC: Rio de Janeiro, 2005.

27. Tundisi, J. G.; Água no Século XXI: Enfrentando a Escassez, Ed. Rima: São Carlos, 2005.

28. von Sperling, M.; Introdução à Qualidade das Águas e ao Tratamento de Esgoto, Depto. de Engenharia Sanitária e Ambiental, UFMG: Belo Horizonte, 2005, vol. 1. 


\section{NITROUS OXIDE EMISSIONS FROM AN INTERMITTENT AERATION ACTIVATED SLUDGE SYSTEM OF AN URBAN WASTEWATER TREATMENT PLANT}

William Z. de Mello*, Renato P. Ribeiro e Ariane C. Brotto

Departamento de Geoquímica, Instituto de Química, Universidade Federal Fluminense, Outeiro São João Batista, s/n, $24020-141$ Niterói - RJ, Brasil

Débora C. Kligerman, Andrezza de S. Piccoli e Jaime L. M. Oliveira

Departamento de Saneamento e Saúde Ambiental, Escola Nacional de Saúde Pública, Fundação Oswaldo Cruz, Rua Leopoldo Bulhões, 1480, 21041-210 Rio de Janeiro - RJ, Brasil

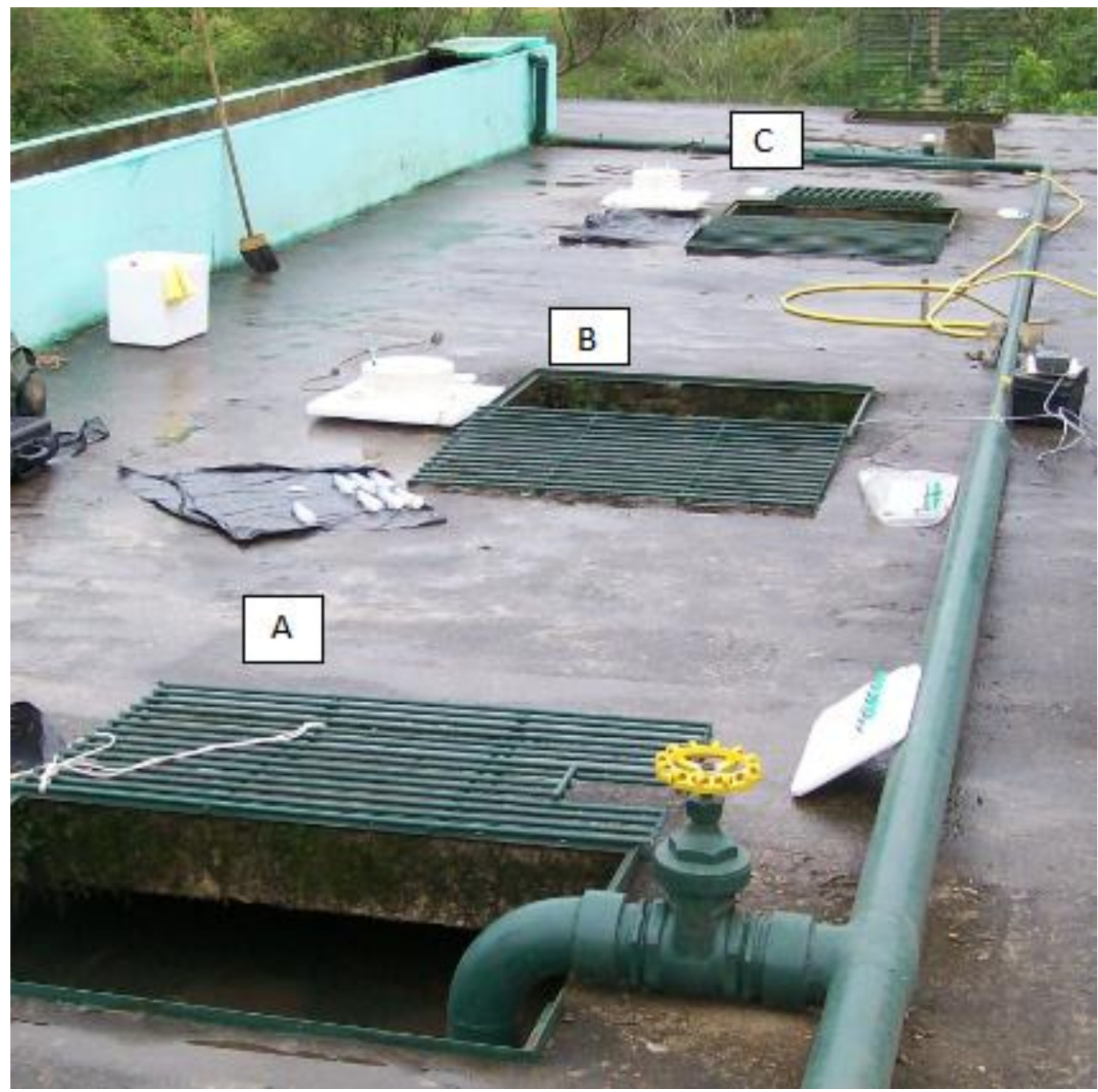

Figure 1S. The covered aeration tank of the wastewater treatment plant and the openings ( $A, B$ and $C)$ through which all measurements were made 